\title{
THE EFFECT OF ENTREPRENEURSHIP ORIENTATION TOWARD MARKET ORIENTATION AND PERFORMANCE OF SONGKOK MSME IN GRESIK REGENCY
}

\author{
Ina Syarifah ${ }^{1}$, Muhammad Kholid Mawardi ${ }^{2}$ and Mohammad Iqbal ${ }^{3}$ \\ ${ }^{1,2,3}$ Fakultas Ilmu Administrasi \\ Universitas Brawijaya \\ Malang
}

\begin{abstract}
Purpose - This research aims to determine the effect of entrepreneurial orientation on market orientation, entrepreneurial orientation on the performance of MSMEs, and market orientation towards the performance of MSMEs.

Design/methodology/approach - The object of this research is Songkok Micro Small and Medium Enterprises (MSME) in Gresik Regency.

Findings - The results of this study indicate that entrepreneurial orientation has a significant effect on market orientation, entrepreneurial orientation has a significant effect on the performance of MSMEs, and market orientation has a significant effect on the performance of MSMEs.

Practical Implications - The entrepreneurial movement plays a role in economic development in Indonesia. Although the number of entrepreneurs in Indonesia is still relatively low compared to other Southeast Asian countries, according to the 2015-2016 GEM Indonesia Report survey, the intention of entrepreneurship in Indonesia is high compared to Singapore, Thailand, Vietnam and Malaysia.

Originality/value - This research uses a cluster sampling method involving 163 respondents and uses PLS (Partial Least Square) analysis tools with SmartPLS 3.0 software.

Keywords - Orientation; Market Orientation; Performance of MSMEs
\end{abstract}




\section{INTRODUCTION}

The entrepreneurial movement plays a role in economic development in Indonesia, therefore efforts to support Micro, Small and Medium Enterprises (MSMEs) are strategies for developing entrepreneurship in Indonesia (Tambunan, 2006). According to BPS (2016), Indonesia only has $3.1 \%$ of entrepreneurial actors out of a total population of 252 people. The data shows that even though Indonesia has reached the ideal number, Indonesia still lags far behind compared to countries in Southeast Asia, namely Singapore 7\%, Malaysia 5\% and Thailand $4,5 \%$ and Vietnam $3,3 \%$ of the population of each country (www.keminfo.go.id).

Although the number of entrepreneurs in Indonesia is still relatively low compared to other Southeast Asian countries, according to the 20152016 GEM Indonesia Report survey, the intention of entrepreneurship in Indonesia is high compared to Singapore, Thailand, Vietnam and Malaysia. Although there was a decrease from 2013 of $39.5 \%$, to $30.69 \%$ in 2014. However in 015 there was a slight increase of $30.85 \%$. This figure makes Indonesia ranked second after Philippines (www.gemconsortium.org/report).

To develop MSMEs, the improvement in the performance of MSMEs needs to be carried out through ongoing efforts from various institutions and ministries, as well as the banking sector, where coordination is carried out by the MSME ministry. Performance is an illustration of the achievement or achievement of the organization in a certain period. performance can also be defined as a measurement of a company's financial capabilities such as the level of profit, the level of investment with sales growth and profit. Performance can reflect the achievement of the company's financial goals and other objectives 
through the implementation of performance and strategy (Pramesti and Giantari, 2016).

Performance can also be influenced by entrepreneurial orientation and market orientation. Research on the effect of entrepreneurial orientation on market orientation was carried out by several researchers, namely Ruzgar, et al. (2014), Aljanabi and Noor (2015), and Amin, et al. (2016) and Rauch, et al. (2009). The results of Rauch, et al. (2009) found that an entrepreneurial-oriented business tends to benefit because of increased business performance. Furthermore, it was explained that the relationship of entrepreneurial orientation to performance is influenced by the size of the company, the smaller the size of the company, the greater the direct effect of entrepreneurial orientation on performance. Thus entrepreneurial oriented MSMEs will have an impact on superior performance.

Market orientation also affects performance, as stated by Kohli and Jaworski (1990), market orientation is a corporate culture that leads to improved performance. this is supported by the results of Amin, et al. (2016) and Beneke, et al. (2016) who found that market orientation had a significant positive effect on performance. According to Baker and Sinkula (2009), market-oriented companies will have a basis for faster improvements and will be reflected in new product success, productivity, market share, and sustainable competitive advantage.

In 2016 there were more than 1,425 large medium and small industries in Gresik Regency. International-class companies also joined in establishing the industry. The number of industries does not always have a positive impact on society. The establishment of the industry is still concentrated in the Gresik sub-district only, while the other sub-districts 
have only small industries. Besides that the centralized activities in Gresik sub-district have caused the development in Gresik sub-district to grow rapidly, this has led to less attention to development in other regions (www.jatimprov.go.id).

This uneven development has caused a lack of access to transportation and infrastructure so that the younger generation from other sub-districts prefer to find work in the Gresik sub-district which is dominated by large industries. This causes problems for small businesses because of the low interest of the younger generation to continue the business. No exception with MSMEs Songkok, Songkok is one of the superior products that characterizes Gresik regency because it is in accordance with the vision of Gresik regency namely "Realizing Gresik that is Religious, Fair, Prosperous, and Quality in Life". Gresik Regency is also known as Songkok village, because it has a songkok industry spread throughout the village (www.gresikkab.go.id).

Based on data from DinasKoperasi, PerindustriandanPerdaganganGresik Regency, the existence of songkok industry centered in Gresik District is $62 \%$. The remaining $38 \%$ is spread in Kebomas, Sidayu, Bunga, Manyar, Panceng, Ujung Pangkah and BalongPanggangSubdistricts (Gresik Regency in 2017 figures). With the condition of activities that are only centered in one sub-district that causes uneven development and prosperity, it also affects the Songkok industry which is $38 \%$ spread across other sub-districts. This caused its own problems for the songkok industry.

The problems that are often faced by the songkok industry in Gresik Regency which are not yet fully explored include (1) lack of skilled workers due to the lack of interest of the younger generation to work in the songkok industry, (2) songkok industry is a hereditary company, so 
the owners lack entrepreneurial spirit, and (3) the majority of songkok industry owners still leave their products in stores, not market directly to the market. This causes the owner to get less information about the market. Thus further research is needed.

\section{THEORETICAL FRAMEWORK}

1. Entrepreneurship Orientation

Stevenson and Jarillo (1990) analogize the study of entrepreneurial orientation as a concept of entrepreneurial management, reflecting the processes, methods, and styles of organizations acting in entrepreneurship.Dess and Lumpkin (2005) state that companies that want to increase entrepreneurial success must be entrepreneurial oriented. According to Lumpkin and Dess (1996) entrepreneurial orientation is measured by five indicators, namely:

a. Innovativeness, refers to the tendency of individuals or companies to engage and support new ideas, uniqueness, experiments, and creative processes that make it possible to produce new products, services, or processes (technology).

b. Risk Taking, refers to measuring the degree to which individuals or groups or organizations differ in their progress in taking risks and rewards received.

c. Proactiveness, refers to as the first mover and other actions aimed at seeking safety and protecting market share and by looking forward to the perspective reflected in anticipatory actions taken at the request of the future. 
d. Competitive aggressiveness, refers to the intensity of the efforts of an organization or company to issue competitors from the industry. This effort can help to guarantee a high market share and will cause the company to have a good performance.

e. Autonomy, refers to independent actions of an individual or group or organization in bringing up an idea or vision and bringing it to completion.

2. Market orientation

Narver and Slater (1990) also define market orientation as the most effective and efficient organizational culture to create the behaviors needed to create superior value for consumers and produce superior performance for companies especially in a tight competitive environment. In this study, measuring market orientation with 4 (four) indicators (Kolar, 2006), namely: market intelligence, intelligence dissemination, intelligence responsiveness, and marketing culture.

\section{Performance of MSMEs}

Performance refers to the level of achievement or achievement of a company in a certain period. a company's performance is crucial in the development of the company. The company's goals are basically maximizing company value reflected in various performance measures (Ghibson, 1991). Tambunan (2002) revealed that the performance of MSMEs can be seen from several things, namely: (1) the creation of job opportunities, very important in seeing the success or failure of a business. Thus the amount of labor absorbed, the greater the role of MSMEs in overcoming the problem of unemployment. Likewise with productivity, by increasing the labor force used, means productivity is also increased, (2) contribution to Gross Domestic Income (GDP), can occur if MSMEs can provide 
income for the country, in this case both from domestic and foreign sales (export).

In this study, researchers used performance indicators according to Boso, Story, and Cadogan (2013), namely: sales performance and profitability. The growth in quantity of product sales is increasing and the growth in profits is calculated in the increasing nominal value of money (rupiah) and the increasing number of company assets, both fixed assets and non-fixed assets.

\section{METHODE}

This research is an explanatory research with a quantitative approach, the location of the research is located in Gresik Regency and the object of this research is all of the actors of Songkok Micro and Small Medium Enterprises which amount to 163 perpetrators. The method used in probability sampling in this study is cluster sampling, where the type of sampling is often used to reduce the cost of sampling, because the population is spread over a large geographical area. First, the sampling method is to determine the distribution of the sampling area and then select the main sample area, and the sample is chosen randomly to be the object of the research.

The sample size was determined by the method of determining the number of samples according to Slovin in Sevilla, et al. (1960) as follows:

$$
n=\frac{N}{1+N e^{2}}
$$

Dimana :

$\mathrm{n} \quad=$ Number of samples

$\mathrm{N} \quad=$ Population

$\mathrm{e} \quad=$ error tolerance 


$$
\begin{aligned}
\mathrm{n} & =\frac{274}{\left(1+274 \times 0,05^{2}\right)} \\
\mathrm{n} & =163
\end{aligned}
$$

From the calculation of the Slovin formula, it was found the results of the sample amounted to 163 , then the researchers spread the questionnaire directly to all respondents who were willing to fill out the questionnaire. Sample number data based on Subdistrict on the research that has been applied with the proportionate stratified random sampling method include: Gresik Subdistrict: 119, Kebomas: 2, Sidayu: 2, Bungah: 16, Manyar: 11, Panceng: 11, Ujung Pangkah: 1, andBalongpanggang: 1 where the respondent is the owner of Songkok MSME.

This study uses a questionnaire as an instrument in collecting data from respondents, namely the owner or manager of the company. The analysis used in this study is Partial Least Square (PLS). PLS analysis is used to develop hypotheses, predict complex situations, and a feature that facilitates multivariate data analysis. PLS analysis in this study uses SmartPLS 3.0 software. The concept models in this study are as follows:

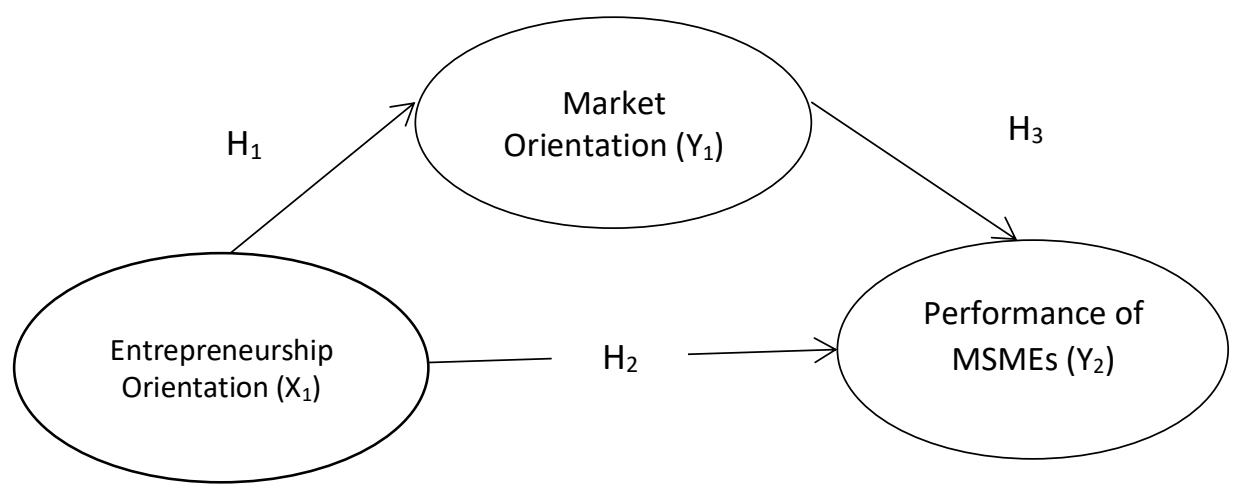

Figure 1.Research Concept Model

From the research concept, the following hypotheses are generated:

1. Entrepreneurship Orientation has a significant effect on market orientation

Vol. 28, No. 2 August 2020

(C) Centre for Indonesian Accounting and Management Research

Postgraduate Program, Brawijaya University 
2. Entrepreneurship Orientation has a significant effect on MSME Performance

3. Market Orientation has a significant effect on MSME Performance

\section{RESULTS AND DISCUSSION}

\section{Research result}

In the PLS analysis there are two tests namely the outer model and inner model. The test results of the outer model in this study are as follows:

1. Convergent validity, aims to determine the validity between indicators and their latent variables. According to Ghazali (2006), the convergent value of validity is said to be sufficient, if the loading value is 0.5 to 0.6 . Convergent validity will be explained in Table 1 .

Table 1. Convergent Validity

\begin{tabular}{|c|c|c|}
\hline Item & Variable & Original Sample $(0)$ \\
\hline X1.1.1 & \multirow{15}{*}{ Entrepreneurship Orientation } & 0.766 \\
\hline X1.1.2 & & 0.772 \\
\hline X1.1.3 & & 0.781 \\
\hline X1.1.4 & & 0.743 \\
\hline X1.2.1 & & 0.791 \\
\hline $\mathbf{X 1 . 2 . 2}$ & & 0.605 \\
\hline $\mathbf{X 1 . 2 . 3}$ & & 0.770 \\
\hline X1.3.1 & & 0.804 \\
\hline $\mathbf{X 1 . 3 . 2}$ & & 0.800 \\
\hline $\mathbf{X 1 . 3 . 3}$ & & 0.779 \\
\hline X1.4.1 & & 0.800 \\
\hline $\mathrm{X} 1.4 .2$ & & 0.772 \\
\hline $\mathbf{X 1 . 5 . 1}$ & & 0.805 \\
\hline $\mathbf{X} 1.5 .2$ & & 0.802 \\
\hline $\mathbf{X 1 . 5 . 3}$ & & 0.776 \\
\hline Y1.1.1 & & 0.788 \\
\hline Y1.1.2 & & 0.825 \\
\hline Y1.2.1 & & 0.831 \\
\hline Y1.2.2 & & 0.837 \\
\hline
\end{tabular}




\begin{tabular}{|c|c|c|}
\hline Y1.3.1 & Market Orientation & 0.837 \\
\hline Y1.3.2 & & 0.818 \\
\hline Y1.4.1 & & 0.854 \\
\hline Y1.4.2 & & 0.816 \\
\hline Y2.1.1 & & 0.741 \\
\hline Y2.1.2 & \multirow{3}{*}{ Performance of MSMEs } & 0.849 \\
\hline Y2.2.1 & & 0.837 \\
\hline Y2.2.2 & & 0.730 \\
\hline Y2.2.3 & & 0.833 \\
\hline
\end{tabular}

The table above shows that all items used in this study are valid because they have a loading value above 0.5 .

2. Discriminant validity, functions as proof that latent constructs predict the size of their blocks better than other blocks (Ghazali, 2014). The discriminant validity of this study will be explained as follows.

Table 2. Discriminat Validity

\begin{tabular}{|l|c|c|c|}
\hline Item & $\begin{array}{c}\text { Entrepreneurship } \\
\text { Orientation }\end{array}$ & Market Orientation & $\begin{array}{c}\text { Performance of } \\
\text { MSMEs }\end{array}$ \\
\hline X1.1.1 & 0.766 & 0.662 & 0.623 \\
\hline X1.1.2 & 0.772 & 0.603 & 0.609 \\
\hline X1.1.3 & 0.781 & 0.641 & 0.596 \\
\hline X1.1.4 & 0.743 & 0.593 & 0.576 \\
\hline X1.2.1 & 0.791 & 0.697 & 0.668 \\
\hline X1.2.2 & 0.605 & 0.466 & 0.462 \\
\hline X1.2.3 & 0.770 & 0.658 & 0.623 \\
\hline X1.3.1 & 0.804 & 0.705 & 0.689 \\
\hline X1.3.2 & 0.800 & 0.682 & 0.646 \\
\hline X1.3.3 & 0.779 & 0.690 & 0.678 \\
\hline X1.4.1 & 0.800 & 0.667 & 0.671 \\
\hline X1.4.2 & 0.772 & 0.672 & 0.602 \\
\hline X1.5.1 & 0.805 & 0.696 & 0.738 \\
\hline X1.5.2 & 0.802 & 0.669 & 0.709 \\
\hline X1.5.3 & 0.776 & 0.677 & 0.685 \\
\hline Y1.1.1 & 0.698 & 0.788 & 0.713 \\
\hline Y1.1.2 & 0.674 & 0.825 & 0.676 \\
\hline
\end{tabular}

Vol. 28, No. 2 August 2020

(C) Centre for Indonesian Accounting and Management Research

Postgraduate Program, Brawijaya University 


\begin{tabular}{|l|l|l|l|} 
Y1.2.1 & 0.657 & 0.831 & 0.696 \\
\hline Y1.2.2 & 0.672 & 0.837 & 0.675 \\
\hline Y1.3.1 & 0.749 & 0.837 & 0.777 \\
\hline Y1.3.2 & 0.731 & 0.818 & 0.744 \\
\hline Y1.4.1 & 0.739 & 0.854 & 0.722 \\
\hline Y1.4.2 & 0.667 & 0.816 & 0.666 \\
\hline Y2.1.1 & 0.677 & 0.623 & 0.741 \\
\hline Y2.1.2 & 0.684 & 0.715 & 0.849 \\
\hline Y2.2.1 & 0.667 & 0.694 & 0.837 \\
\hline Y2.2.2 & 0.578 & 0.613 & 0.730 \\
\hline Y2.2.3 & 0.708 & 0.780 & 0.833 \\
\hline
\end{tabular}

The table above shows that all items in this study have met discriminant validity, that is, each item measures its latent variables higher than the value of other items.

3. Composite reliability, a variable said to be reliable if the AVE value is greater than 0.5, the composite reliability value and Cronbach alpha a construct is declared reliable if the composite reliability and cronbach alpha are above 0.70. The composite reliability and cronbach alpha results are as follows:

Table 3. Goodness of Fit

\begin{tabular}{|c|r|r|rr|}
\hline Variable & \multicolumn{2}{|l|}{$\begin{array}{l}\text { Cronbach's } \\
\text { Alpha }\end{array}$} & Composite Reliability & $\begin{array}{l}\text { Average Variance } \\
\text { Extracted (AVE) }\end{array}$ \\
\hline X1 & 0.951 & 0.957 & 0.597 \\
\hline Y1 & 0.933 & 0.945 & 0.682 \\
\hline Y2 & 0.858 & 0.898 & 0.640 \\
\hline
\end{tabular}

The values in Table 3 show that all variables are said to be reliable with values greater than 0.5 and the cronbach alpha values above 0.7 .

Testing the inner model in this study is shown as follows:

1. R-Square $\left(\mathrm{R}^{2}\right)$ : The R-Square VALUE obtained from this study will be shown in the following Table:

table 4. R-Square

\begin{tabular}{|c|c|}
\hline Variable & R Square \\
\hline Market Orientation & 0.718 \\
\hline Performance of MSMEs & 0.777 \\
\hline
\end{tabular}

The R-Square value indicates that $71.8 \%$ of market orientation variable (Y1) can be influenced by entrepreneurial orientation variables, while the 
remaining $28.2 \%$ is influenced by other variables outside the research. Y2 RSquare value is $77.7 \%$, which means that the performance variable of MSMEs can be influenced by entrepreneurial orientation and market orientation, while the remaining $22.3 \%$ is influenced by other variables outside the research.

2. Hypothesis testing results

Table 5. Hypothesis testing

\begin{tabular}{|l|r|r|r|r|r|}
\hline & \multicolumn{1}{|l|}{$\begin{array}{l}\text { Original } \\
\text { Sample (O) }\end{array}$} & $\begin{array}{l}\text { Sample } \\
\text { Mean (M) }\end{array}$ & $\begin{array}{l}\text { Standard } \\
\text { Deviation } \\
\text { (STDEV) }\end{array}$ & $\begin{array}{l}\text { T Statistics } \\
(\mid \mathbf{O} / \text { STDEV|) }\end{array}$ & P Values \\
\hline X1->Y1 & 0.848 & 0.848 & 0.042 & 20.390 & $\mathbf{0 . 0 0 0}$ \\
\hline X1->Y2 & 0.362 & 0.371 & 0.106 & 3.398 & $\mathbf{0 . 0 0 1}$ \\
\hline Y1->Y2 & 0.554 & 0.545 & 0.114 & 4.874 & $\mathbf{0 . 0 0 0}$ \\
\hline
\end{tabular}

From testing the hypothesis it is known that all research hypotheses are accepted because they have a p-value below 0.05 , which means that all variables have a significant effect.

\section{DISCUSSION}

1. Effect of entrepreneurial orientation on market orientation

Entrepreneurial orientation has a significant positive effect on market orientation with a correlation coefficient of 0.848 or $84.8 \%$, which means that when the entrepreneurial orientation variable is increased once, the market orientation variable will increase by $84.8 \%$.

The results of this study support the results of previous studies conducted by Amin, et al. (2016). Which states that there is a strong influence between entrepreneurial orientation on market orientation. The results of this study also support the concept put forward by Naver and Slater (1996), namely entrepreneurial orientation can increase prospects for developing products or identifying underserved market segments, both of which are opportunities to develop competitive competitiveness. In addition, market-oriented companies will encourage innovative companies that are able to create new product concepts that refer to market needs. Likewise with companies that are proactive in identifying and responding to competitors quickly, thus giving the best impact on a market orientation culture.

2. Effect of entrepreneurial orientation on the performance of MSMEs

Vol. 28, No. 2 August 2020

(C) Centre for Indonesian Accounting and Management Research

Postgraduate Program, Brawijaya University 
Entrepreneurial orientation has a significant positive effect on the performance of MSMEs with a correlation coefficient of 0.362 or $36.2 \%$, which means that when the entrepreneurial orientation variable is increased once, the variable performance of MSMEs will increase by $36.2 \%$.

The results of this study support the results of previous studies conducted by Ruzgar, et al. (2014), Amin, et al. (2016), Asad, et al. (2016), and Lee and Chu (2017) which state that the influence of entrepreneurial orientation on performance is significantly positive. The results of this study are also in line with the concept proposed by Lumpkin and Dess (1996) which states that companies that want to increase their entrepreneurial success must be entrepreneurial oriented. Further explained that companies with entrepreneurial orientation will become more innovative, where companies have the ability and are willing to support creativity, new ideas, and experiments that produce new products or services.

3. Effect of market orientation on the performance of MSMEs

Market orientation has a significant positive effect on the performance of MSMEs with a correlation coefficient of 0.554 or $55.4 \%$, which means that when the market orientation variable is increased once, the variable performance of MSMEs will increase by $55.4 \%$.

The results of this study support the results of previous studies conducted by Amin, et al. (2016) and Beneke, et al. (2016) who found that market orientation had a significant positive effect on performance. The results of this study are also in line with the concept proposed by Kohli and Jaworski (1993) which states that market orientation is the result of developing a marketing concept consisting of customer focus, coordinated marketing and profitability. Of the three things, customer focus and coordinated marketing are the things that underlie market orientation, while profitability is a consequence.

\section{CONCLUSION}

Based on the results of the research described in the previous chapter, the conclusions produced are as follows: 
Entrepreneurial orientation has a significant positive effect on market orientation in Songkok MSMEs in Gresik Regency. The higher the entrepreneurial orientation of a company, the higher the market orientation. Likewise, if the entrepreneurial orientation is low, the market orientation is also low.

Entrepreneurial orientation has a significant positive effect on the performance of Songkok MSMEs in Gresik Regency. The higher the entrepreneurial orientation, the higher the performance of MSMEs.Vice versa, the lower the entrepreneurial orientation, the lower the performance of MSMEs.

Market orientation has a significant positive effect on the performance of Songkok MSMEs in Gresik Regency. The higher the market orientation, the higher the performance of MSMEs. Vice versa, the lower the market orientation, the lower the performance of MSMEs.

\section{Limitation}

This research was conducted in one place, namely the district of Gresik, East Java and this study focused on one MSME sector only, the SMSE's of songkok, therefore the result of this study might be different if examined in other cities and other sectors.

\section{Thanks to}

Thank you too DinasKoperasi, Perindustrian, Perdagangandan UMKM Gresik Regency which has helped provide business identity and MSME data, and thanks to Songkok Micro and Small Medium Enterprises in Gresik Regency.

Entrepreneurial orientation has a significant positive effect on the performance of Songkok MSMEs in Gresik Regency. The higher the entrepreneurial orientation, the higher the performance of MSMEs. Vice versa, the lower the entrepreneurial orientation, the lower the performance of MSMEs.

Market orientation has a significant positive effect on the performance of Songkok MSMEs in Gresik Regency. The higher the market orientation, the higher the performance of MSMEs. Vice versa, the lower the market orientation, the lower the performance of MSMEs.

\section{Limitation}

Vol. 28, No. 2 August 2020

(C) Centre for Indonesian Accounting and Management Research

Postgraduate Program, Brawijaya University 
This research was conducted in one place, namely the district of Gresik, East Java and this study focused on one MSME sector only, the SMSE's of songkok, therefore the result of this study might be different if examined in other cities and other sectors.

\section{Thanks to}

Thank you too Dinas Koperasi, Perindustrian, Perdagangan dan UMKM Gresik Regency which has helped provide business identity and MSME data, and thanks to Songkok Micro and Small Medium Enterprises in Gresik Regency. 


\section{REFERENCES}

Aljanabi, Abdul Qadir Rahomee Ahmed and Nor Azila Mohd Noor. 2015. The Mediating Role of Market Orientation on Entrepreneurial Orientation, Absorptive Capacity and Technological Innovation Capabilities. Asian Social Science, Vol. 11, No. 5.

Amin, Muslin et. al. 2016. The Effect of Market Orientation as a Mediating variabel in the Relationship Between Entrepreneurial Orientation and SMEs Performance. Nankai Business Review International Vol. 7 No.1, pp. 39- 59.

Baker, W. E., and Singkula, J. M. 2009. The Complementary Effect of Market Orientation and Entrepreneurial Orientation on Profitability in Small Businesses. Journal of Small Business Management, 47, 443-464.

Bekene, Justin, et. al. 2016. The Efect of Market Orientation and Learning Orientation on Organizational Performance (A Study of Small to MediumSized Enterpises in Cape Town, South Africa). Journal of Research in Marketing and Entrepreneurship Vol. 18 No. 1, pp. 90-108.

Boso, N., Cdogan, J. W. and Story, V. M. 2013. Entrepreneurial Orientation and Market Orientation as Drivers of Product Innovation Success: a Study of Exporters from a Developing Economy. International Small Business Journal, Vol. 31 No. 1 pp 57-58.

BPS. 2016. Perkembangan UMKM pada Periode 2016. Diakses 25 Januari 2018. http://www.bps.go.id.

Dess, G.G and Lumpkin, G.T. 2005. The Roke of Entrepreneurial Orientation in Stimulating Effective Corporate Entrepreneurship. Academy of Management Executive, Vol 19, No. 1, Hal. 147-156.

Ghozali, Imam. 2006. Aplikasi Analisis Multivariate dengan Program SPSS (Edisi Ke 4). Semarang: Badan Penerbit Universitas Diponegoro.

Ghozali, Imam 2014. Structural Equation Modelling: Metode Alternatif dengan Partial Least Square (PLS). Semarang: Universitas Diponegoro Semarang.

Gibson, James L., et al. 1991. Organizational Behavior, Structure, Processes, Seventh Edition.

USA Boston: Richard D. Irwin, Inc. 
Global Entrepreneurship Monitor. 2016. GEM Global Entrepreneurship Monitor. Diakses pada tanggal 23 Oktober 2017 dari www.gemconsortium.org/

Gresikkab. 2017. Dokumen RPJMD Pemkab. Diakses 19 Juni 2018 di www.gresikkab.go.id

Jatimprov. 2017. UKM Jatim Sumbang PDRB. Diakses 18 Juni 2018 di www.jatimprov.go.id

Keminfo. 2017. Peluang Besar jadi Pengusaha di Era Digital. Diakses 18 Juni 2018 dari www.keminfo.go.id

Kohli, Ajay K. and Jaworski, B. J. 1990. Market Orientation: The Contruct, Reserch Proposition and Managemnet Implication. Journal of Marketing, Vol. 54, p.1-18.

Kolar, T. 2006. Benchmarking market orientation of bank in transitional markets: exploring a modified approach. Marketing intelligence and planning, 23 (1), 104-113.

Lumpkin, G.T. and Dess, Gregory G. 1996. Clarifying the Entrepreneurial Orientation Construc and Linking it to Performance. The Academy of Management Review, Vol 21, No 1, 135-172.

Narver, John C and Stanley F. Slater. 1990. The Effect of a Market Orientation on Business Profitability. Journal of Marketing, Vol. 54, p. 20-35.

Pramesti, Ni Made Vera and I Gusti Ayu Ketut Giantari. 2016. Peran Orientasi Pasar Memediasi Pengaruh Orientasi Kewirausahaan terhadap Kinerja UKM Industri Kerajinan Endek. E- Jurnal Manajemen Unud, Vol. 5, No. 9, 5754-578.

Rauch, A., et al. 2009. Entrepreneurial Orientation and Business Performance: An Assessment of Past Research and Suggestion fot the Future. Entrepreneurship Theory and Practice, Vol. 33, pp. 761-787.

Ruzgar, Nursel Selver, et al. 2014. The Mediating Effect of Market Orientation on the Relationship betweeN Entrepreneurial Orientation and Performance. Researchgate.net/publication/270822288.

Sevilla. 1960. Pengantar Metode Penelitian. Jakarta: Universitas Indonesia. 
Stevenson, H. H. and Jarillo, J. C. 1990. A Paradigm of Entrepreneurship: Entrepreneurial Management. Strategic Management Journal, (Special Issue) 11, $17-27$

Tambunan. 2002. Usaha Kecil dan Menengah di Indonesia: Beberapa Isu Penting. Salemba Empat: Jakarta. 